\title{
False Blister Beetles, (Insecta: Coleoptera: Oedemeridae) ${ }^{1}$
}

Ross H. Arnett, Jr. ${ }^{2}$

\section{Introduction}

"False blister beetles," sometimes known also as "pollen feeding beetles," are unique in that adults of all the approximately 1,000 species in the world are obligate pollen feeders. They obtain their common name because many species cause blisters when pinched or squashed against the skin. Being pollen feeders, they are often common on flowers. They are also attracted to lights, and their numbers can be vast at night, especially on the Florida Keys. Oxycopis mcdonaldi (Arnett) causes skin blistering and makes itself a nuisance at resort areas where the beetles are attracted by night lights around swimming pools, tennis courts, and open air restaurants. Yet another species, Nacerdes melanura (L.), the "wharf borer," is common around wood pilings where its larvae bore into and weaken the wood of docks and adjacent buildings.

\section{Description}

Adult beetles in the family Oedemeridae have a length of 5 to $12 \mathrm{~mm}$. Their tarsi have five segments on front and middle legs and four segments on the hind legs (tarsal formula 5-5-4). The next to last segment is heart shaped with pad beneath. Tarsal claws are entire or with a small basal tooth. The pronotum is without lateral ridges (which separate them from the Cantharidae and Lampyridae which they somewhat resemble). The pronotum is widest in the front half, narrowing toward elytra (which separate them from the Meloidae, true "blister beetles," which have the pronotum narrowed in front). The head is porrect (extending forward horizontally) and in the same plane as the thorax, with prominent mandibles which may be entire at tips, or one, or both, bifid (celft or divided into two parts). The maxillary palpi have the apical segment somewhat enlarged and usually triangular. The eyes are usually emarginate near the base of the antennae. The elytra is entire, sides more or less parallel, their apices rounded.

\section{Life Cycle}

The life cycle of a few species is known. Adults mate on flower heads during pollen feeding. Both sexes feed on pollen, which acts as a congregating attractant, but the female will not accept the male

1. This document is EENY-154 (originally published as DPI Entomology Circular 259), one of a series of Featured Creatures from the Entomology and Nematology Department, Florida Cooperative Extension Service, Institute of Food and Agricultural Sciences, University of Florida. Published: September 2000. This document is also available on Featured Creatures Website at http://creatures.ifas.ufl.edu. Please visit the EDIS Website at http://edis.ifas.ufl.edu. Additional information on these organisms, including many color photographs, is available at the Entomology and Nematology Department website at http://entnemdept.ifas.ufl.edu/.

2. Ross H. Arnett, Jr., Florida Department of Agriculture and Consumer Services, Division of Plant Industry, Gainesville, FL.

The Institute of Food and Agricultural Sciences is an equal opportunity/affirmative action employer authorized to provide research, educational information and other services only to individuals and institutions that function without regard to race, color, sex, age, handicap, or national origin. For information on obtaining other extension publications, contact your county Cooperative Extension Service office. Florida Cooperative Extension Service/Institute of Food and Agricultural Sciences/University of Florida/Christine Taylor Waddill, Dean. 


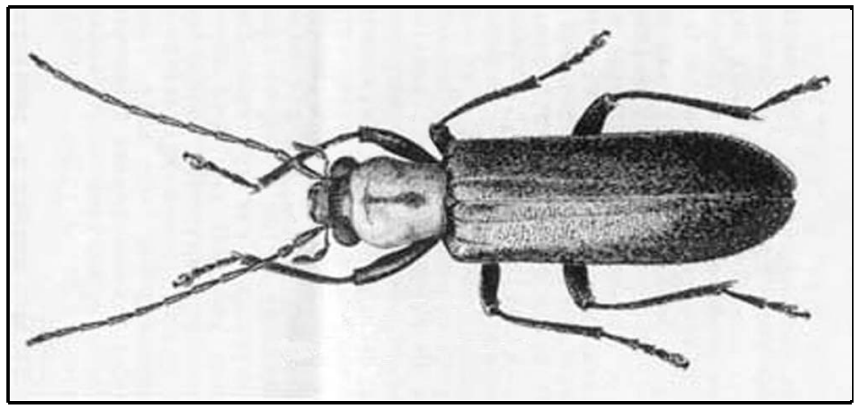

Figure 1. Adult Oxycopis mcdonaldi (Arnett) (Oxycopiini). Credits: Division of Plant Industry

until her gut is packed full of pollen. The pollen is stored in a special intestinal sack, in which an enzyme causes the pollen to partially germinate, enough to cause the pollen test (an indigestible covering) to rupture. The pollen grain contents are then digested and used in the manufacture of eggs. Eggs are laid under bark of nearby trees. Larvae hatch, drop to the ground, bore into damp soil and complete their larval life. In the soil they probably feed on rootlets and fungal rhizomes. Pupation takes place in the soil, and adults emerge to continue the yearly cycle. So far as known one cycle takes place each year, and this is timed to coincide with the blossoming of certain flowers. Other species have larvae which bore into driftwood, pilings, decaying wood, debris, and some make vertical tunnels in moist soil. Adults of some species prefer the pollen of a single plant species, while others are found on a variety of hosts.

\section{Medical Importance}

The life cycle of a few species is known. Adults mate on flower heads during pollen feeding. Both sexes feed on pollen, which acts as a congregating attractant, but the female will not accept the male until her gut is packed full of pollen. The pollen is stored in a special intestinal sack, in which an enzyme causes the pollen to partially germinate, enough to cause the pollen test (an indigestible covering) to rupture. The pollen grain contents are then digested and used in the manufacture of eggs. Eggs are laid under bark of nearby trees. Larvae hatch, drop to the ground, bore into damp soil and complete their larval life. In the soil they probably feed on rootlets and fungal rhizomes. Pupation takes place in the soil, and adults emerge to continue the yearly cycle. So far as known one cycle takes place each year, and this is timed to coincide with the blossoming of certain flowers. Other species have larvae which bore into driftwood, pilings, decaying wood, debris, and some make vertical tunnels in moist soil. Adults of some species prefer the pollen of a single plant species, while others are found on a variety of hosts.

\section{Taxonomy}

Florida has 29 species of Oedemeridae assigned to eight genera. These figures are interesting when compared to the oedemerid fauna of the West Indies, where 33 species belonging to seven genera occur. Of these species, 11 also occur in Florida. The following is a list of the species known or thought to breed in Florida, along with a brief account of their distribution and a list of the plants on which they have been taken.

A key to the New World genera may be found in Arnett (1961), and descriptions of most of the Nearctic species are in Arnett (1951). A checklist of the species known to occur in North America, including Central America and the West Indies, may be found in Arnett (1983). A key to the following genera and species is included below.

\section{Annotated List of Florida Oedemeridae}

\section{Nacerdinae}

\section{Nacerdini}

Nacerdes melanura (L.) (the Wharf Borer). This species was found in Gainesville in a box sent from New York, and also was collected in Gulf County in a boat. It occurs in every state in the U.S.A., but apparently is not established in Florida. The species was introduced from Europe through commerce. Larvae breed in driftwood and pilings in marine and fresh water.

Xanthochroa erythrocephala (Germar). The known plant host of this species is Cornus anomum Miller, but undoubtedly adults are attracted to other flowers in the spring. It has been collected in May in Florida, in Liberty and Duval counties. The species is confined to the southeastern states. 
Xanthochroa lateralis (Melsheimer). This species is also rare; Alachua and Liberty counties in Florida, with additional specimens known from South Carolina.

Xanthochroa trinotata LeConte. Until 1980, this species was unknown in Florida. It was taken in Lake City (Columbia County) along the Santa Fe River. Previously it was known from Louisiana and Alabama.

\section{Oedemerinae}

\section{Asclerini}

Asclera puncticollis (Say). This large genus is represented in Florida by this species, taken at Torreya State Park, Liberty County. However, it is widespread in eastern U.S.A. where it is found on blossoms of Prunus spp. It also apparently was introduced into California.

\section{Oxycopiini}

Oxycopis notoxoides (Fabricius). This species is common in northern Florida and along the west coast south to Manatee County where adults are found on a variety of flowers including palm blossoms, clover, Ilex spp., and Ceanothus spp. It is found from New Jersey south to Florida, west to Arkansas and eastern Texas.

Oxycopis thoracica (Fabricius). Adults are found on flowers throughout Florida from December through June, but are most abundant in April and May. It occurs throughout eastern United States.

Oxycopis vittata (Fabricius). This species is widespread throughout the West Indies, with a few specimens taken in the Florida Keys (Monroe county) and in Dade County.

Oxycopis suturalis (Horn). Although known from New Jersey southward through Florida, and west to Louisiana, it is most common in Florida, especially in the Florida Keys (Dade and Monroe counties). Adults are found on flowers of papaya, palmetto, and Metopium toxiferum (Linnaeus).

Oxycopis mimetica (Horn). This species is known from New Jersey, south to Florida and west to
Iowa, Kansas, Arkansas, and Texas. Florida records are from central Florida south to Lee County. Adults are collected at lights and in Steiner traps.

Oxycopis floridana (Horn). This is an uncommon species taken in Dade and Monroe counties (Florida Keys) except for one collection in Martin County. It also is found in Bimini, B.W.I. According to F. Strohecker (in litt.) it "swarms on the flowers of black mangrove and buttonwood in the spring."

Oxycopis mcdonaldi (Arnett). This species is often a pest because of the great numbers swarming around lights and landing on people. If they are touched or crushed, they cause skin blistering. The species is taken along the coast from Levy County south to Key West and north along the east coast to Volusia County. It also occurs in the Bahamas and in Cuba. Some specimens have been taken from the flowers of corn.

Oxycopis dietrichi (Arnett). This rare species is known in Florida from specimens taken at Plantation Key. It is also found in Mississippi and in Belize, Central America.

Oxycopis falli (Blatchley). Adults of this species were first found by Blatchley by sweeping a fleshy crucifer on the beach near Cape Sable. It is known from Florida, ranging from Titusville and Cedar Key south through the Florida Keys (Dade and Monroe counties), and in the West Indies in the Bahamas, Grand Cayman, and the Dominican Republic.

Specimens are taken by sweeping various grasses, and on oleander and corn flowers.

\section{Oedenerini}

Heliocis repanda (Horn). Adults of this species appear in early April and continue to be abundant until early May in northern Florida as far south as Sarasota County. It is also known from Texas south into Mexico but is absent in the Florida panhandle, Alabama, Mississippi and Louisiana. Records of plant hosts include a variety of plants such as blackberry, blueberry, oak, stinking ash, and fleabane. 


\section{Oxaciini}

Oxacis taeniata (LeConte). Known from the coasts of North Carolina, South Carolina, Georgia, and Florida, this species likely breeds in saline situations, but larvae are unknown. It is not found on the west coast of Florida, but it does occur in the Bahamas. Adults fly as early as March and as late as July. The only host plant record is on oleander.

Oxacis laeta (Waterhouse). This species is distinctly West Indian, but has invaded Florida in Dade and Monroe counties. Adults have been taken from mid-April through July attracted to lights. The sole plant host record is "collected on coconut palm buds." Larvae of this species are the only ones known for the genus. The species is not typical of the genus and may be misassigned. One adult was reared from larvae taken in vertical burrows in the sand a few yards from shore in Everglades National Park. The larvae move up and down the burrow, but there is no evidence that they are predators. I suspect they may feed on algae.

Oxacis trirossi Arnett. Although widespread throughout southern United States., and common in Mexico, this species occurs sparsely in Florida as far south as Hardee County. It apparently is associated with willow and cottonwood flowers. Oxacis trirossi is recorded as far north as Lafayette, Indiana, near the Wabash River, and South Dakota, near the Missouri River. No doubt this species follows river banks where willows and cottonwoods are abundant. Many Florida specimens, however, were found on citrus fruit.

Paroxacis recendita (Arnett). This is a common species known from Mexico north to Texas and east to southern Georgia, with two records in Florida (Bay and Okaloosa counties). It seems to be a littoral species found on the flower heads of sea oats, Uniola paniculata (L.).

Paroxacis interrita (Arnett). Often common in southern Florida, this species is found as far north as Osceola County. Nothing is known about its biology; all specimens have been taken around lights.

\section{Hypasclerini}

Hypasclera pleuralis (LeConte). Another coastal species, it is found on the flower heads of sea oats, Uniola paniculata (L.) and also on Croton punctatus Jacq. The species is distributed from Virginia south to Florida and west to Texas and Mexico. It has also been taken in the Bahamas and the Dominican Republic. Florida records include nothing but coastal localities in Indian River, Dade, Levy, and Taylor counties.

Hypasclera floridana (Horn). Nothing is known about the biology of this coastal species. It is known from Florida, the Bahamas, and one record from Alabama. All Florida records are confined to the Florida Keys (Monroe and Dade counties), except for one collection at Biscayne Bay (the location of the original specimens from which the species was described) and another from Dunedin, Pinellas County.

Hypasclera dorsalis (Melsheimer). This species is often common along the Atlantic coast from Long Island south through Florida, west to Brownsville, Texas, and south into Mexico to Veracruz. Larvae have been reared from rotting wood and decaying $\log$ s along the shore in Florida and in stumps in a saline swamp in Virginia. Florida records include most of the coastal counties.

Hypasclera megateles (Arnett). This species is known solely from Florida where it is abundant on the Florida Keys (Monroe and Dade counties). It is found as far north as Volusia County, but this is uncommon. There is one record of it being taken on flowers of Rhizophora mangle L., but it probably is abundant on other mangroves as well since is comes to lights in large numbers.

Hypasclera pseudosericea (Arnett). This rare species has been taken on the flowers of saw palmetto in Clay, Alachua, Putnam, Volusia, Osceola, and Indian River counties. Adults are attracted to lights in May and June.

Hypasclera nesiotes (Arnett). An abundant species found on islands, never on the mainland, known in the Bahamas, Haiti, Cuba, Puerto Rico, and the Florida Keys (Monroe and Dade counties). Most 
specimens have been taken at lights, but one lot was taken by sweeping grass.

Hypasclera ignota (Arnett). This is another east coast species known from South Carolina, Georgia, and the east coast of Florida to the Florida Keys (Monroe County). Few specimens have been collected. It is similar to the species which follows.

Hypasclera schistacea Kirsch. This species is included here because it may be a senior synonym of H. ignota (Arnett). The Kirsch species is the type species of the genus Hypasclera which seems to be congeneric with Alloxacis Horn, the name under which Florida species of Hypasclera were originally included. H. schistacea Kirsch is known from Colombia and Panama. It is not impossible that it could range all the way to Florida, but until more specimens are located, this problem cannot be solved. Meanwhile, the two species are considered valid.

Hypasclera costata (Champion). One specimen of this species was taken at Baldwin (Duval County). The scattered localities elsewhere range from St. Vincent, Jamaica, Dominican Republic, Cuba (in the West Indies), and Maryland, Virginia, Alabama, Mexico, Guatemala, Honduras, Nicaragua, and Panama (on the mainland). Most of the United States records are from cargo interceptions. It seems unlikely this species is established in the United States. The biological records pertain to specimens collected in banana debris at ports.

\section{Key to the Species of Oedemeridae of Florida}

1. Front tibiae with a single apical spur (Nacerdinae, Nacerdini) . . . . . . . . 2

1 '. Front tibiae with 2 apical spurs (Oedemerinae) ........... 5

2(1). Distance between eyes in dorsal view more than twice width of 1 eye (Nacerdes) . . . . . . . . . . N. melanura (L.)

$2 '$. Distance between eyes in dorsal view less than twice width of 1 eye (Xanthochroa) ...... 3

3(2). Elytra with testaceous sutural markings; thorax orange with black markings . ...... 4
3'. Elytra without testaceous sutural markings; thorax black with central orange stripe . . . . . . . . . .....X. erythrocephala (Germar)

4(3). Thorax with central black stripe and each side with large black spots; front with 2 black spots or rarely with a median stripe or nearly immaculate . . .............. X. trinotata LeConte

4'. Thorax with lateral spots only; head immaculate .......... X. lateralis (Melsheimer)

5(1). Eyes lateral, small, rounded, at most only very slightly emarginate; mandibles bifid at apices (Oedemerini) ........ Heliocis repanda (Horn)

5'. Eyes dorso-lateral, moderate to large, definitely emarginate near base of antennae, usually reniform; mandibles entire, or 1 , or both mandibles bifid ..............6 6

6(5). Mandibles both apically bifid . . . . 20

6'. Mandibles both entire, or left entire and right bifid ............

7(6). Both mandibles entire, or at most with slight apical groove ........ 8

7'. Mandibles with right only bifid, left entire (Hypasclerini) ............ 13

8(7). Mandible with slight apical groove which gives appearance of a worn, slightly bifid condition (Oxycopiini); body metallic blue-brown . . . . . . . . ...... Oxycopis falli (Blatchley)

8'. Both mandibles entire; body color various (Oxaciini) . . . . . . . . . 9

9(8). Claws all with basal tooth (Paroxacis) .... ............... 10

9'. Claws never with a distinct basal tooth, at most quadrate at base (Oxacis) . . . . . 11

10(9). Elytra testaceous with a distinctly limited humeral stripe extending to apex ............ ....... P. interrita (Arnett)

10 '. Elytra fusceous or dark with indistinctly limited sutural and narrow humeral stripe $\ldots \ldots \ldots \ldots$ ............ P. recendita (Arnett) 
11(10). Prothorax with lateral margins only stained with piceous, central stripe absent . . . . . . . ........... O. taeniata (LeConte)

$11^{\prime}$. Prothorax immaculate or distinctly marked with spots or central stripe . . . . . 12

12(11). Thorax broad in front, length to width ratio $1: 1$; surface of thorax between punctures finely reticulate; pronotum with 6 large, merging spots and a central variable stripe ........ O. laeta (Waterh.)

$12 '$. Thorax narrower in front, length to width ratio 5:4; surface of thorax swollen between punctures; prothorax immaculate or with a central stripe only ........ O. trirossi (Arnett)

13(7). Claws at most quadrately dilated at base; elytra pale, each with a median fuscus vittae attaining apex ............ dorsalis (Melsheimer)

13'. Claws usually acutely toothed at base, or, if not, elytra without vittae attaining apex . . . . 14

14(13). Both thorax and elytra dark with metallic reflections, at most with indistinct markings . ....H. ignota (Arnett) and H. schistacea (Kirsch)

14 . Thorax pale; elytra usually with vittae ... .................. 15

15(14).Elytra entirely pale, without vittae ..... ........... floridana (Horn)

15 '. Elytra dark or with vittae $\ldots \ldots \ldots 16$

16(15). Each elytron with a median pale vitta extending to apex .....H. pseudosericea (Arnett)

16'. Elytra, if with a median pale vitta, never extending beyond middle ........ 17

17(16). Each elytron with broad lateral vitta dark and contrasting with pale area $\ldots \ldots \ldots \ldots \ldots H$. pleuralis (LeConte)

17'. Elytra without pale vittae ....... 18

18(17). Thorax always immaculate; elytra without sutural area pale, or rarely very narrowly so . ............... nesoites (Arnett)
18'. Thorax with central dark spot, and/or lateral spots or stripes $1 \ldots \ldots \ldots 19$

19(18). Pronotum with central spot and lateral margin dark; elytra with broad, pale sutural vittae . . . ............ megateles (Arn.)

19 '. Pronotum with lateral margins only dark; each elytron with a narrow lateral, dark vitta ........ .........H. costata (Champion)

20(6). Claws toothed at base; pronotum with 3 deep impressions arranged in a triangle and with a large central dark spot (Asclerini) . . . . . . . . . . .... Asclera puncticollis (Say)

20 '. Claws at most quadrate at base, without tooth near base or apex (Oxycopiini) (Oxycopis) .... ................. 21

21(20). Maxillary palpus with apical segment widest near apex; pronotal punctures sparse . . . . . . . .......... O. vittata (Fabricius)

21'. Maxillary palpus with apical segment widest near base; pronotal punctures usually dense . . ..............22

22(21). Elytra with well marked costae; white hairs on costae denser, giving appearance of white stripes .......... O. luteostriata (Arnett)

22'. Costae of elytra obscure; elytra without white stripes . . . . . . . . . 23

23(22). Thorax orange; elytra dark . . . . 24

23'. Thorax and elytra of different color combination. . . . . . . . . . . . 27

24(23). Elytra metallic green . . . . . . . . . . . . O. mcdonaldi (Arnett)

24'. Elytra piceous . . . . . . . . . . . 25

25(24). Elytra with narrow sutural stripe testaceous ......... O. mimetica (Horn)

25'. Elytra immaculate ........... 26

26(25). Thorax immaculate ..... O. thoracica (Fabricius) 
26'. Thorax with 2 basal spots . ...........

......... O. notoxoides (Fabricius)

27(23). Elytra each with a broad median piceous stripe; thorax with broad lateral stripes . . . . . . . . . ...... O. dietrichi (Arnett)

27'. Elytra with narrow marginal stripe fusco-piceous and thorax with lateral spots or appearance varying to entirely piceous; $9-12 \mathrm{~mm} . .$. ................. Suturalis (Horn)

\section{Selected References}

Arnett, R.H., Jr. 1951. A revision of the Nearctic Oedemeridae (Coleoptera). Am. Midl. Nat. 45:

257-391.

Arnett, R.H., Jr. 1961. Contribution toward a monograph of the Oedemeridae. 14. A key to and notes on the New World genera. Coleopt. Bull. 15: 49-64.

Arnett, R.H., Jr. 1983. Family 119. Oedemeridae (first series), in Arnett, R.H., Jr., Checklist of the beetles of North and Central America and the West Indies, vol. 6. The darkling beetles, Strepsiptera, and related groups. Gainesville: Flora and Fauna Publ., 6 p.

Denmark, Harold A. 1959. Twenty-Second Biennial Report. Bulletin State Plant Board of Florida 2 (13): 86.

Herms, W.B. 1925. Entomological observations on Fanning and Washington Islands, together with general biological notes. Pan-Pacific Ent. 2: 54.

Kurosa, K. 1977. Poisonous beetles (Oedemeridae, p. 126-129) in Sara, M., Takabasi, H., Kano, R., and Tanaka, H. Animals of medical importance in the Nansei Islands in Japan. Tokyo, Shinjuku Shodo, 410 p.

Vaurie, Patricia. 1951. Blistering caused by oedemerid beetles. Coleopt. Bull. 5: 78-79. 